\title{
A QUALITATIVE STUDY: WHO ARE THE SOCIAL WORKERS?
}

\section{SOSYAL BILIMLER \\ DERGISI}

\author{
NİTELIKKSEL BİR ÇALIŞMA: SOSYAL ÇALIŞMACILAR \\ KIMLERDIR?
}

ANKARA UNIVERSITY

JOURNAL

OF

SOCIAL SCIENCES

\section{Tuğbat CANBULUT}

Araş. Gör, Sağlık Bilimleri Fakültesi, Sosyal Hizmet Bölümü,

tugba.canbulut@istanbul.edu.tr

10.33537/sobild.2021.12.1.14

\section{Makale Bilgisi}

Gönderildiği tarih: Kabul edildiği tarih: Yayinlanma tarihi:

11.10.2020

30.12.2020 30.01 .2021

\section{Article Info}

Date submitted: Date accepted:

Date published:

11.10.2020

30.12 .2020

30.01 .2021

\section{Keywords}

Social workers; Social policy; Social welfare; Social welfare state.

\section{Anahtar sözcükler}

Sosyal Çalışmact; Sosyal Politika; Sosyal Refah; Sosyal Refah Devleti.

\section{Abstract}

This study is a social policy criticism based on the perception of social workers by the state. Social workers seem to have an important role and authority in the implementation of social policies. In the study, through interviews with 21 social workers working in Turkey it has collected data on the role and powers. The interviews were conducted in the form of in-depth interviews. The study is part of a master's thesis which was supported by Scientific Research Projects Office of Istanbul University. Throughout the study, narratives about how the state saw social workers were discussed. Social workers interviewed shared narratives that the state saw themselves as a mediator, passive policy enforcer and opponent. However, social workers are equipped to direct the policies to be implemented due to their professional formations. In addition to claiming that they should be active in politics, it is an important result of this study that they have aims to increase social welfare. In this context, this study, they exposed the social workers in Turkey by introducing the rat race argues that the social welfare policies need to be revised.

\section{$\ddot{O} z$}

$\mathrm{Bu}$ calıșma, sosyal hizmet uzmanlarinin devlet tarafindan algılanmasina dayalı bir sosyal politika eleştirisidir. Sosyal hizmet uzmanlarinin, sosyal politikalarn uygulanmasinda önemli bir rol ve yetkiye sahip olduğu görülmektedir. Calıșmada, Türkiye'de çalışan 21 sosyal hizmet uzmaniyla yapilan görüşmeler sonucunda, rolleri ve yetkileri hakkinda veri toplanmiștır. Görüșmeler, derinlemesine görüșmeler şeklinde yapılmıştır. Çalışma, İstanbul Üniversitesi Bilimsel Araştırmalar Proje Birimi tarafindan desteklenen yüksek lisans tezinin bir parçasıdır. Calıșma boyunca devletin sosyal hizmet uzmanlarını nasıl gördüğüne dair anlatılar tartışılmıştır. Sosyal hizmet uzmanlar, devletin kendisini bir arabulucu, pasif politika uygulayıcısı ve muhalif olarak gördüğüne dair anlatılar paylaștı. Ancak sosyal hizmet uzmanlan mesleki oluşumlan nedeniyle uygulanacak politikalara yön verecek donanima sahiptir. Siyasette aktif olmalar gerektigini iddia etmelerinin yant sira sosyal refahı artırmayı hedefledikleri bu çalışmanın önemli bir sonucudur. Bu bağlamda, Türkiye'deki sosyal hizmet uzmanlarinı ortaya çıkaran sıçan yarışını ortaya koyan bu çalışma, sosyal refah politikalarının revize edilmesi gerektiğini savunmaktadır. 


\section{Introduction}

Social workers are actors who are important for social welfare and social policy studies as the faces of the social policies of the states. But what should social workers actually do and where are they positioned by the government? It is believed that the answers to these questions can shed light on three important issues: (1) how states shape their social policies, (2) how people relate to the state, (3) what kind of social service formation is organized for state.

In this context, this study by social workers who work in Turkey, uses data from the negotiations on the perception of social workers in Turkey. Social workers work with the majority of society their unfavorable position compared to others. The interpretation of how social workers are positioned by the "employer" state has provided an opportunity to obtain very important data in this study.

In the study, primarily located in a section that provides background to the academic literature research on the social worker in Turkey. This section, where conceptual definitions of social workers are kneaded with professional content, is followed by a method section describing how the work is done. The methodology section also mentions all the situations that the researcher faces during the study, and it is thought that seeing the process as a whole in qualitative researches contributes significantly to the study.

The findings of the study were obtained through indepth interviews with social workers. In the findings and discussion section, the narratives of social workers about how the state sees themselves is mentioned: the state sees them as intermediaries, opponents and unqualified. After discussions, the study completes with the conclusion section.

\section{Conceptual Framework: To Be A "Social Worker" In Turkey}

According to International Social Work Federation, "Social work is a game changer. Social workers work in communities with people finding positive ways forward in the challenges they face in their lives. They help people build the kind of environments in which they want to live, through co-determination, co-production and social responsibility. Economic health cannot be achieved without social health "(https://www.ifsw.org/what-is-social-work/, Access Date: 11.6.2020).

According to Barker's (1999: 453) definition, social services are used to improve the health and well-being of people. It is a whole of activities carried out by social workers and other professionals to help individuals, families, groups or communities successfully fulfill their social functions in preventing people's dependence on others and strengthening their family ties. Social work is a profession that has the knowledge, methods and skills that can be intervened in raising awareness of the individual in terms of using his freedom of decision for his own benefit, creating the necessary change in terms of being an efficient element in society by adapting to the changing socio-economic conditions and normative system of his environment. (Kut, 1988: 16). Employees of the profession are social workers, who are in a position to qualify as the pulse of the field of social services, they do expected work focusing on disadvantage. In general terms, these jobs, which include a number of professional interventions with individuals, families and groups who are exposed to or are likely to be excluded from social exclusion for various reasons, are services that are offered to a wide audience. As Gökçearslan Çiftçi and Gönen (2011: 155) stated, it is sometimes difficult to balance the interests of the society with the interests of the client. While it is somewhat understandable that the applicants prefer economic support to psychosocial support, the important thing is to question the social structure and the role of the state in this matter that leads them to this interest.

In addition, in order to be aware of the provision of social services as "right" to the customer, it is imperative that practitioners feed more than critical social work practice and applicants gain more visibility as a political issue (Atasü Topçuoğlu, Akbaş, 2016: 180). The social worker should have the ability to perceive, evaluate and interpret the individual and the world surrounding it beyond what is visible. Only in this way can it serve social change and social justice (Tuncay, Erbay, 2006: 54).

It is seen in many countries that social services between citizens and the state are gradually changing from being an obligation of the state, while social services are changing, with social policies shifting from the human focus to the market focus, devastating from planning, resources and infrastructure (Atasü Topçuoğlu, Akbaş, 2016: 177). Individuals become powerless as long as they are objects rather than subjects of social change and do not take part in the construction of social reality. (Tuncay, Erbay, 2006: 66).

The professional focus of social work can be defined as increasing the level of social welfare by solving social problems. At this point, in the processes of analyzing social problems, determining the underlying needs of these problems and implementing policies and practices to meet these needs, social services make great use of the social policy field (Denney 1998: 36). According to Berkük (2010: 101) correctly detected adoption by the social work profession of institutions and society, especially the distribution of social justice and was felt intensely the problems in increasing social welfare is of critical importance in developing countries such as Turkey. Social workers, who are the professional representatives of the social work profession, contribute to the process of solving the problems of individuals of different ages and needs groups, which are of interest to the social work profession (Danış, 2007: 58). Social workers try to increase social change and social justice 
on behalf of their clients. (Gökçearslan Çiftçi, Gönen, 2011: 149)

Social workers take their power from the laws and carry out their professional practices within the framework of official social and economic policies. They carry out their professional knowledge and skills acquired during the training process by adhering to legal regulations and the working area of the social service institution they work for (Denney 1998: 30). Social service intervention aims to help the clients to access the resources so that they can meet social and vital demands (Gökçearslan Çiftçi, Gönen, 2011: 153). In this case, the legal regulations applied by social workers are also expected to facilitate the access of the clients to the resources. However, the point that Atasü-Topçuoglu and Akbaş (2016: 179) convey from Healy (2000: 2-3) should be carefully pointed out: According to most activists, the traditional understanding of social work tends to see the situation of the clients dealing with personal and social problems as a defect. However, critical social workers should claim to steer towards the elimination of the original structural causes of the problems faced by the service users.

Confusion about social services in Turkey is primarly seen in the identification of social workers. Professionals who are considered as social workers within the scope of the study are also defined as social workers (SW) / social service worker (SSW) in the field. The concept discussion on nomenclature remains confusing in each of the academic, administrative and field parts of the business. Undoubtedly, it is not just an education system problem that causes this conceptual difference. This issue is also discussed in the social policy axis. Professionals working in the field of social services are not only graduates of the social work department. Occupational groups such as sociologists, psychologists, teachers, child development specialists, pedagogues are also regarded as "social service worker" with a roof name that destroys their own professional names. The concept of social worker is a social movement undergraduate graduate, who regards the profession as a political movement for the disqualification of the profession. In the following sections, this issue is discussed with quotations from the interviews.

The definition of the professional member other than those described above may also differ (in content) depending on the job description drawn by the institution in which it works. For example, the job description of the Ministry of Family Labor and Social Services, which is envisaged to provide expert employment, is as follows: "Social worker: Refers to graduates from institutions providing education in the fields of psychological counseling and guidance, psychology, sociology, child development, teaching, family and consumer science, and social work." (http://www.mevzuat.gov.tr/MevzuatMetin/ 1.5.5395.pd f, Update Date: 30.04.2015). Karakuş (2015: 182) says that, a decision issued by the general manager of the Social Services Child Protection Agency in 2007, has been instructed not to use titles other than the staff title. In order to stay away from the socio-political debate of the concept and to highlight the evaluation through the eyes of the interviewees, their professional expression has been respected.

\section{Methodology}

The study consists of a part of the research carried out within the scope of the master's study. The sample of the study was formed by selecting social workers working as professors in Istanbul and Ankara as snowballs and the negotiations ended at the point of the research. The data of 21 interviewers were used within the scope of this study. The study is a qualitative research and continued with in-depth interviews with interviewers. During the interviews, the voice recordings taken with the permission of the interviewers were stopped if they so desired, so that the participants were able to answer the questions without feeling uncomfortable. Data analysis was done by deciphering the sound recordings and dividing the transcriptions into categories and codes. In accordance with ethical concerns, the names of the interviewers were coded as "X (number)" and the places where they worked were not said.

In the data received within the scope of the study, the ages or genders of the interviewers were not an effective variable in the way they dealt with the subject. Their professional experience has created a language difference only in the transfer of experiences related to the transformation of the profession.

The validity and reliability of the research is to consider validity and reliability according to qualitative research principles. What makes a qualitative research reliable is to ensure consistency both in application and analysis. It is believed that consistency and robustness, and hence reliability, are achieved in recording and using data (via voice recording) in a consistent manner in both practice and analysis. On the other hand, since validity represents accuracy and qualitative research does not proceed only on a line, there is a different perception of validity in this study. Accuracy is handled as transferring information that has not been distorted and transforming this information into data and an attempt has been made to ensure validity over individual lines without being tied to a single line. Although the concepts of validity and reliability are used together and leave the impression that they support each other, these concepts may also contradict. In this study, while reliability, in other words, a consistent trend was generally provided, the validity of the data obtained with a consistent application style - due to the lack of a single focus - could vary. While taking data close to each other increases reliability, the differentiation of the platforms on which these data are evaluated led to the questioning of "accuracy" in the data. As a result, since this research is based on a perception study and the interview subjects have close business areas and common professional formations, the answers given by 
each interviewer were respected, while consistency was provided.

The limitation experienced in the research regarding the recording of the voice from the interviewers can be related to the data collection period of the research. It should be noted that the research was conducted with members of a profession group who considered themselves "opposed" to a "any" government in general because of their position of "being with people who have been infringed".

\section{Findings And Discussion}

In this section, the findings of how the state sees the interviewees are discussed with various supports from the literature. Accordingly, an interviewer 's execution analogy said, "My teacher always said something, we are social workers, we take people from the rope and we take them to the rope." (X.6, 2014) keeping the words aside along the following two sections seems to be appropriate. Although this point of view expresses a situation that can be generalized, it is desired to underline that the essential thing is that the roles of the experts in social policy determination should be rearranged and deployed at the level of a rights-based social state.

\section{Social Worker as A Profession Between State and Clients}

As a historical mission, social service has been advocating for discriminated and oppressed groups since its birth and contributed to the change of social policies to improve the social welfare of these groups (O'Melia, Miley and DuBois 1998: 12; act. Danış, 2007 : 58). This transfer of the counseling is included in the section where the findings are discussed as a subject that the social workers interviewed frequently emphasize. In addition, the minister said that the management of the Republic of Turkey and examining the number of politicians related to social work in the parliament shows that there is actually a way to social policy from social services. Because there is no minister or deputy who has received social work education in the assembly. Representation in state administration does not come from the bottom. Karatay (2007: 315) states that the demand for a social worker did not turn into a demand from the bottom, as there is not enough organization in the public sector in general, such as the field of social work, health, education, and local governments. Which resulted in the state seeing social workers as a mediator with its citizens.

Under the scope of this study, Ministry of Family, Labor and Social Work (MFLSW), which has taken a significant part of the fight against poverty, is considered as the point representing the state. The place and importance of MFLSW in the context of this policy within the scope of this struggle is explained by an interviewer as follows:
"Before, the perspective was different. A viewpoint towards producing a little more policy. It was a little different in our social work. It was more practiceoriented than policy. Problem solver. Now something has happened to make some more policy" (X.5, 2014).

While the view and mission of the ministry is seen as such, it is very important that the interviewees, who argue that the state, social workers, as the implementer of the social policies produced by the government and the neo-liberal system to protect the power, are the means of establishing the link between individuals and the state.

"It sees us as the main employee of this ministry, but it's a lie. Normally, it actually sees us as the lowest employee. It is seen at the bottom. Let them stay here" (X.7, 2014). It should be noted that, as the interviewee quoted above highlights, not to be seen as a basic employee is actually the basis of the social policy that is desired to be implemented. The solid construction of the ground allows the policy to turn into service in parallel direction. The information added by the same interviewee with the following sentence shows that social workers are used both as a ground and a backbone. "There is already a minister's words in the past, we see you as the backbone of this ministry. The reason is, you carry the load, we manage it" (X.7, 2014).

Another social worker who thinks that he is the mediator of the state with the economic support package offered under the fight against poverty is as follows: "The state, unfortunately, sees social workers as a means of social aid, to save the day. I think the help provided is absolutely insufficient. Looking at the conditions, the minimum wage is also insufficient” (X.3, 2014).

It is noteworthy that the interviewer, who stated that he found the inadequacy of the aid provided with the economic support package as a social service application, hoped to be seen as a part of a system that does not aim to bring the client to the level of well-being. It seems appropriate to continue the narratives of the interviewees who think that they cannot really do their job properly:

"The state has to produce policies to meet its own needs rather than the existence and importance of our profession. Or he prefers. Because it is also a political material for them. That's why it doesn't need to understand our profession right now. Because there is also a charity culture event that comes with history. Since we often produce policies to cover the problem of those who need it, rather than taking protective or preventive measures, this is a common problem in the perception of the profession, since this is our general habit" (X.4, 2014).

In the same context, another interviewee emphasizes not being aware of the importance of the profession but not wanting to be understood. The reason for this is that the state sees the social worker only as a practitioner of temporary solutions: "You will do the works of the state, 
but the education you receive from your professional opinion does not matter much while doing those works. What needs to be done is determined by legislation, you cannot exceed it" (X.5, 2014).

Professional formation is neglected. Complaints of being restricted as a profession group implementing the legislation required by the existing social policy rather than the teaching and requirements of the professional formation. In addition, another interviewer who argues that personal comments added to the profession have also been neglected, with the words "There is no point in being you" (X.6, 2014).

The following comment brought by one of the social workers who explained their position as an intermediary in the context of making the professional formation trivial takes the issue to a different dimension: "We are used to be mediator, we were an intermediary that brought the resources of the state and the needy together. People did not know, to learn how to make use of the state's resources" (X.8, 2014). The interviewer says that while being a mediator, it can perform as a task during the equitable distribution of the state's resources, while implementing their professions with a hardware that carries out awareness and informative work, they have been transformed into a protector of the state's resources, not the applicants. Another social worker says: "When I talked to social workers, they were actually punished for what they did. A lot of things that don't touch others touch them. Behold, people who did not expect expertise before, when a problem occurs, the social worker did not work. But what did you provide to the social worker, what did you do as the administration, nobody is looking at it!” (X.9, 2014).

The fact that the social workers who exceed the lines determined by the political authorities during the practice of professional teachings are being questioned because of both their work and the things they cannot do, emphasizes not only their wear, but also the desire of the state to control: "The state says that it actually needs social workers, but it wants to use social workers in some way. It wants to use social workers as a mediator to create a dependent society in some way, but also wants to keep social workers under control as they create a force against it" (X.10, 2014).

Saying that the desire to keep their mediators under control is not a government-specific situation, but also a product of all power, the social worker says that the profession is thought to have a structure that serves power: "Whoever takes the sword of democracy, says I'm the king" (X.18, 2014).

\section{Social Worker as Opponents of the State}

While social workers play a role in the production and distribution mechanisms of social welfare as a professional structure within the state, they should take a radical, critical and opposing stance against social policy practices and goals that can harm the functioning of social justice. (Berkün, 2010: 100) In support of this wish, in addition to blinding their professional skills as their mediators, social workers say that the state sees themselves as an opponent of the state.

"Actually, we are one side as a profession. Since we are a party, we are a group that constantly conflicts with the authority. We look a little bit more like we are working with people whose sociocultural level of society is lower and who are outside the circle. The greatest thing of capitalism is to get rid of the social state. But we also say 'no! the social state will fulfill its requirement! When you are in this dilemma, you seem to be opposed" (X.10, 2014).

Explaining the reason of his opposing appearance as a part of his goal of becoming a social state, the social worker also provides information about the group he works for. The professional approach of social workers, who are on the poor side of social inequality, including their resistance to the status quo, causes the status quo to see themselves as confrontational. It is also striking that the "not able to be silence" by another social worker who stated that they were not on the side of the administrative structures of the state because they defended the ones at the bottom of the hierarchical structure in the state system: "You see the deficits. You see injustices to people, or you see unfair behavior in aids. You feel that you need to do something as a state or as a profession, you express it" (X.11, 2014)

While explaining the reason why the interviewer is not able to be silence and therefore opposed, the transfer of a vocal group that stands against social injustice is the expression of how important social workers are in the social service pillar from their own language. Another point emphasized by the interviewed social workers while expressing that the state sees opposition is the narrative that opposition formation is a duty assigned to them by the state: "The state sends us towards itself, there. Go, it says, fight against me" (X.15, 2014). The interviewer, who states that the state uses social workers as part of the field and is fed from this situation in order to create self-study, describes the job as "fighting". The narrative of the same interviewee, "The state is throwing us over to harm itself," also makes it possible to conduct a social policy analysis structured to eliminate losses.

As a result of the functioning of the social service, it is important to create an audience that needs this issue and becomes open to management with this need. It is precisely at this point that Thompson (2013: 26) is complicated by the place where social work discipline is located, the role and structural position it plays in relation to the problems or dirty work of the society. The "structural positions" of social workers, who are the field practitioners of the social work discipline, and the "dirty jobs" in the middle, are perhaps the most important part of a state-organized social policy on the fight against poverty. As a complement to the structure fed by the presence of dirty works, a different interpretation about whether social workers who think that they are 
equipped with an opposing identity are questioning whether they are the applicants or the system they provide is as follows: "In other words, we are looking at all the problematic people who vomit outside that the society cannot solve in itself. We take care of them. As such, it becomes a little bit of the conscience of society. In other words, the one whose conscience is uncomfortable attacks us" (X.18, 2014).

Although the most clients who are served are seen as individuals who exist at various stages of the society as a social problem, attention should be paid to the emphasis on "conscience" in this transference. Social workers who try to bring the poor individuals who have become the conscience of the society to the level of welfare perform a profession based on a kind of conscience relief. Another indication that the institutions and organizations where social workers work is conscientiously serving the conscience of those institutions and / or organizations. Conscience is one of the important criteria that ensures the feasibility of the "activating social resources" issue in which the expert takes office. The section on social assistance and philanthropy discussions discusses the conscientious aspect of the social work profession in more detail. But what is essential to say here is the reality that the social worker serves.

It is necessary to include the words of the social worker, who interprets the social workers interviewed as opposed to the state in the eyes of the state, as a political threat to the professional formation dynamics. One of the social workers who stated that they were considered as a threat, said: "The presence of a social in our name harmonizes a direct ideology. There is prejudice, from people and institutions" (X.4, 2014). The social worker, who started his speech by explaining that some ideological designs as a presenter of social work can be the cause of prejudice even with only social emphasis, cites the reason for the assumptions that they pose a political threat about the source of prejudice as follows: "Political prejudices lead us to a labeling. We have to work as human rights. But this particular patriarchal structure, especially when you work on women's rights, is like doing a political work" The interviewer, who carried the opposition of his profession to the political arena, emphasizes that it is perceived as a disadvantage by the state to advocate within the paternalist system.

Explaining being a political threat with the emphasis on "social" and the context of the paternalist perspective, the interviewer is accompanied by a more general view of the social worker: "Professionals working with people are seen as a threat by the state. How much you empower people, they will create channels that can be included in the management" (X.12, 2014).

This interpretation of the expert, who makes a general comment by associating being an opponent and also a political threat not only with expertise, but with all the professions that try to increase the welfare of the human, can be analyzed by combining it with the previously mentioned dirty work issue. That is to say, it is not maximizing the welfare level that the state power expects from the social worker and even any professional group working with people. Rather, it is about covering the dirty works with superficial cleaning and making them sustainable and manageable with sustainability. As a power, the state, which does not want to emerge another power with high intervention power, therefore makes social workers feel opposed.

\section{Social worker as an unqualified professional}

The public service preserves its "excitement and importance" throughout its history of more than 5000 years; it resembles an "adventure" with "dangers and opportunities" for public officials (Shaftritz, Russell, 2000: 35; act. Öktem, 2006: 43).

Other important points that draw attention in the records in which the social workers interviewed talk about themselves and their professions in the eyes of the state are the interpretations of the social workers' being unqualified, not recognized and emptied of the profession. Social workers describe the efforts of the state to make their work as a profession group above all a priority: "The state has a social policy and supports certain needy people through this policy. They have a well-established system and, as their social welfare levels are high, they are progressing by closing the problems that arise now. But since we have no such tradition, this is something imported like laws, such as the constitution, since it is not built on need, it is now seen from above as something that is also done for the European Social Charter. While this is considered as a profession abroad, it is seen here as a charity institution that everyone can do, as a result of perception and mentality" (X.4, 2014).

Other social workers also have support phrases about the issue of turning into a job that everyone interviewed can do. "We have undervalued in terms of personal rights. I feel it. This is done consciously. For example, something called a social worker emerged. You may have heard. It makes this profession so ordinary that it can make this profession to anyone. And as soon as everyone becomes able to do, the higher the value of a person, the higher the fee he gets, but the more he makes it worthless that anyone can do it. When he gets ordinary, the salary he gets or the salary he will pay becomes so worthless. For this reason, the salary that social workers are currently receiving is below the poverty line. People who work in this profession receive wages that they never deserve, and I also include other professionals" (X.10, 2014). "So, he no longer wants specialized professional staff. Anyone can do any job, anyone can do any job after a 6-month and 3-month certificate program. For example, here they give things to prepare a social review report to other professionals, but not only to prepare that report, but if you give it to everyone" (X.13, 2014). 
"I say in the state right now, either everyone is trying to do everyone's business. So this applies to you (sociologist) and to psychologists. Politics is too much right now. You feel it. You are a minority" (X.14, 2014).

Ordinating a profession is an obstacle for individuals belonging to that profession to form an organizational culture. It is also a situation that paves the way for facilitating their repression and management by not being able to carry out organized struggles. The interviewees, who stated that the discomfort of being seen as a "job" that everyone can do and that this view is proceeding on the basis of de-qualification, also say that they do not have professional recognition. "The social workers do not even know what they are doing, even the state does not know" (X.18, 2014). The fact that the social workers, whose legal regulation of what they are doing is actually working, is working with other professional groups determined by the direction of the political wind under the name of multi-discipline. "Social work is a multi-disciplinary field. But within the multi-disciplinary field there are no agricultural engineers, metalwork teachers, or handicraft teachers. They are included in a system that frustrates their meaning and meaning" (X.1, 2014).

An interviewer, one of the members of the unqualified profession group, explains that this is a management tactic, saying: "We fought with the teachers because you cannot do our job. They were on top, we thought we were protecting our profession. It has nothing to do with. They broke it apart. They dropped each other. 26 years after I could not even imagine what the specialist should do, I realized that I was not doing anything except the regulation that the state put before me. But that's not the social worker. This was not" (X.18, 2014).

Another issue emphasized by the interviewees is the lack of professional recognition. Social workers report their efforts to explain themselves as follows: "In Turkey, I think social workers struggle for existence, struggle for existence. It's like being, we are, there is such a profession! ” (X.21, 2014).

The struggle for assets actually includes the stages of being visible / accepted / valued. The fact that the social work profession, which has been formalized with the education system since the 1960s, is still struggling to be recognized, can be attributed to the unwillingness of a strong professional organization. "No validity like a teacher, no nurse. They did not know our profession. I witnessed a patient living in the toilet of an old mosque, cleaning the rate. I wanted to start procedures to be taken into institution care. I was told that what is needed is that we already provide monthly financial aid. At this point, everything is over with me already. I guess I could show you the institution's view of me and my profession" (X.16, 2014). The example of nurses and teachers is meaningful here. Because the social worker in this narrative also states that he has internalized teaching and nursing, which are among the organized professional groups, as valid professions. As seen in this narrative, professional groups that can demonstrate a strong will through their professional organizations are within the scope of "valid profession" even in the eyes of the social worker. The effort to prove himself and his "invalid profession" is described by another social worker with more professional experience than the previous one: "We are not a very lucky professional group. Unfortunately, we always tried to prove ourselves. So I entered the university in 1982, we are still trying to prove ourselves. Then we would try to explain the social worker, we could not. One day I said, my psychologist. After that, they started to explain their problems. At that time we used to go to the way of the Faculty of Agriculture, I would say, I am an agricultural engineer. We always had to prove ourselves to such a situation" (X.2, 2014).

This unrecognized occupational group is also rendered unqualified once again by ignoring its ideas. "The Social Service Child Protection Institution was not very professional, had a dear sergeant relationship but was more sincere, had a family structure, a peasant sincerity. Now, career experts at the ministry are involved. These experts are not from the field, they do not know the field, they do not know the process, they do not know the troubles. And social workers were pushed aside as professions and started not to be involved in any projects or events. He fell into a profession that was not respected" (X.19, 2014).

Another social worker explains that these jobs will not work with those who do not know the business or who do not know the process: "Actually, the laws and regulations that directly affect us. If they make the laws and regulations, by taking care the opinions of us or at least the association of social workers, we will have no problems" (X.17, 2014).

\section{Social Worker as a Government Officer Against Government}

Another point that draws attention in the views received from the social workers about how the state sees the social worker is the narratives of only the interviewers working in the field of health that the state considers themselves as the profession that harms the budget. "For example, it says to me that you don't have a benefit for me. The point of view is this ministry of health" (X.20, 2014).

Again, another interviewer working as a social worker in the ministry of health details the issue of being seen as a loss to the budget: "The state has a financial loss from this point of view, but I think this is not a loss. Unfortunately, these are also in the constitution, Turkey is a social state. So Turkey is a social state, must look to people regardless of financial status. The employees say something to me in the hospital, the social doctor" (X.15, 2014).

Social work is one of the tools used by the state to fulfill social justice. Because there is a redistribution of resources by the state (Küçükkaraca, 2004: 21). In other 
words, the state has to deliver the budget allocated to the needy in order to present social welfare and social justice equally. And the state does this through social workers. While this is the case, the fact that the work done by the social worker is seen as a loss is a situation that should be looked at by questioning. Social workers who give their opinions on this issue are the employees of the Ministry of Health. The fact that the social worker is known as a "social doctor" because of his efforts to provide social welfare rather than a medical service where he works can be considered as an example showing the professional makeshift in the ministry of health.

In addition, some interviewees talk about a different dimension of the issue of harming the state budget by talking about the social and economic support package. This money for the education of children is also part of the family's subsistence strategy. Taking the child into institutional care both changes the form of the child's family subsistence strategy and increases the amount the government spends from the budget for child care. In this way, it can be said that the social worker who provides the "unspentful" economic support to individuals is strived for the sustainability of the system rather than the welfare level of the client. A social worker explains the part of sustainability, which has become the advantage of power, as follows: "I know that the time of the election said to us, give it to everyone, don't discriminate between the applicants" (X.14, 2014).

In this meeting, the direction that the social worker claims to have provided economic support without discrimination, especially during the election period, should be evaluated. This alleged orientation shows that the government uses the economic support that the social worker tries to offer the client within the framework of certain criteria. Here, it turns the social worker into a tool that serves this purpose.

\section{Conclusion}

With this study it is shown that social workers in Turkey are not acting according to the social services according to the requirements of the state's expectations. As a matter of survivability, the state ignores the discourse of social workers with their professional equipment. This ignoring is a neoliberal policy. The state needs a mediator to communicate with the public. Of course, this mediator has knowledge about human behavior and social environmental effects, and the ability to manage crisis. But what the state expects is more obedience than these features. Thus, the state does not allow the social worker to use his qualification as it should be. The social worker who cannot use his qualification is the face of the state visible to the client. In this case, the social worker is the reflection of the state to the applicant. Thus, citizens who depend on various aids of the state, and hence on that state (government), accept the social worker who comes to their door as a representative of the state and allow the state to intervene in their homes.
Another important result is that while the profession is rendered unqualified, other professions are dragged into this chaos. Turkey does not have enough businesses in the field of social sciences, people from different professions are forced to accept any job that works as a social worker. This situation causes various problems between social worker licenses and others. The state also uses these problems in its favor.

Perhaps the most important goal of social work is to strive for a rights-based social welfare environment. There is no doubt that they learned what should be done for this in their education. But in order to use these teachings, the state must first respect them and then open their way. In order for social workers to be in a strengthening position, their mandate must first be strengthened, the most important output of this study.

\section{References}

Akbaş, E. (2014). Sosyal Çalışmada Çağdaş Eleştirel Perspektifler. Ankara: SABEV.

Atasü Topçuoğlu, R. and Akbaş, E. (2016). Küreselleşme Sürecinde Daralan Sosyal Haklar ve Türkiye'de Sosyal Hizmet Sunumunda Yaşanan Dönüşümün Kuramsal ve Politik Çerçevesi, Berlin Humboldt Üniversitesi-Hacettepe Üniversitesi, http://webcache.googleusercontent.com/search?q= cache:q1or9upiqk8j:www.sosyalhaklar.net/2009/bil

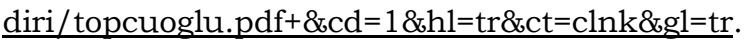
(accessed 13 April 2020)

Barker, L.R. (1999). The Social Work Dictionary. USA: NASW Press.

Berkün, S. (2010). Sosyal Hizmet Uzmanlarının Çalışma Hayatında Karşılaştıkları Mesleki Sorunlar: Bursa Örneği. Toplum ve Sosyal Hizmet 21(1): 99-109.

Danış, M. Z. (2007). Sosyal Hizmet Mesleği Ve Disiplininde Sosyal Politikanın Yeri Ve Önemi. Toplum ve Sosyal Hizmet 18(2): 51-64.

Denney, D. (1998). Social Policy and Social Work. New York: Oxford University Press.

Gökçearslan, Ç. Gönen, E. (2001). Sosyal Hizmet Uygulamalarında Etik Karar Verme Süreci. Toplum ve Sosyal Hizmet 22(2): 149-160.

Karakuş, B. (2015). Sosyal Hizmet Mezunlarının Kadro ve Unvanı Sosyal Hizmet Uzman1/ Sosyal Çalışmac1. Toplum ve Sosyal Hizmet 26(2): 169-190.

Karatay, A. (2007). Cumhuriyet dönemi çocuklara ilişkin politikanın oluşumu. Unpublished $\mathrm{PhD}$ thesis. İstanbul: Marmara Üniversitesi.

Kut, S. (1988). Sosyal Hizmet Mesleği, Nitelikleri, Temel Unsurları, Müdahale Yöntemleri. Ankara. 
Küçükkaraca, N. (2004). Küreselleşme, Sosyal Adalet ve Sosyal Hizmetler, 6. Ulusal Sosyal Hizmetler Konferansı Küreselleşme Sosyal Adalet ve Sosyal Hizmetler. Ankara: Sosyal Hizmet Uzmanları Derneği Genel Merkezi.

International Social Work Federation. (2020). https://www.ifsw.org/what-is-social-work/ (accessed 11 June 2020).

Öktem, M. K. (2006). Kamu Yönetimi Tartışması Bağlaminda Sosyal Hizmetler. Toplum ve Sosyal Hizmet 17(2): 41-57.

T.C. Başbakanlık Mevzuatı Geliştirme ve Yayın Genel Müdürlüğü,

http:/ / www.mevzuat.gov.tr/MevzuatMetin/ 1.5.539 5.pdf (accessed 30 April 2015).

Thompson, N. (2013). Kuram ve Uygulamada Sosyal Hizmeti Anlamak Ankara: Dipnot Yayınları.

Tuncay, T. and Erbay, E. (2006). Sosyal Hizmetin Temel Hedefi: Sosyal Adalet Güçlendirmeyle Retorikten Pratiğe. Toplum ve Sosyal Hizmet 17(1): 53-69. 